Egyptian J. of Nutrition Vol. XXXIII No. 3 (2018)

\title{
Biological study of the effect of some antioxidants both separately and mix them to chronic renal
} failure

\author{
Rasha Haji Hassan Ashkanani \\ Home Economics Department, Basic Education College, The Public \\ Authority for Applied Education and Training, Kuwait
}

\begin{abstract}
The main objective of the present study is to evaluate the ability of the antioxidants (Vit. C, Vit. E \& Selenium) supplement with diet to prevent the development on chronic renal failure in the experimental rats. Rats $(n=42)$ were randomly divided into six equal groups and treated for four consecutive weeks. The first group continued to receive the same diet without supplement until the end of the study (control group). The second group fed on diet containing adenine $(0.75 \%$, w $/ w$, in feed) (adenine diet) as a control positive group. The third group fed on adenine diet supplemented with $3 \mathrm{~g}$ vitamin $\mathrm{Cl} \mathrm{kg}$ diet. The fourth group fed on adenine diet supplemented with $900 \mathrm{mg}$ vitamin $\mathrm{E} / \mathrm{kg}$ diet, and the fifth group fed on adenine diet supplemented with $0.1 \mathrm{ppm}$ of selenium as sodium selenite. The sixth group fed on adenine diet supplemented with antioxidants mixture. Results showed that uric acid, urea nitrogen and creatinine $(\mathrm{mg} / \mathrm{dl})$ of the control positive group showed significant increase $(P \leq 0.05)$ the mean values of kidneys decrease than that of the positive control group especially the groups fed on adenine diet containing (selenium \&mixture of all antioxidants) as compared to (control -) group. AST and ALT enzymes in all treated groups




\section{Rasha Haji Hassan Ashkanani}

recorded significant decrease $(P<0.05)$ when compared with (control + ). Histopathological examination of kidneys of rat from group the groups which treated with Vit. C, Vit. E and the mixture of (vitamin C, Vitamin $E$ and selenium) revealed no histopathological changes. Vit. $\mathrm{C}$, Vit.E and selenium improved kidney function and its complications resulting from chronic renal failure. According, it could be recommended that consuming adequate amount of antioxidants from foods and added selenium in the preparation of bread or bakery.

\section{Introduction}

Renal failure is accompanied by oxidative stress, which is caused by enhanced production of reactive oxygen species and impaired antioxidant defense. (Wesen,2011) The suggested therapeutically interventions aimed at reducing oxidative stress in chronic renal failure patients are as follows:1) Administration of antioxidants [alpha-tecopherol, ascorbic acid, $\mathrm{N}$-acetyl cysteine, reducing glutathione].2) Substances possibly affecting oxidative stress indirectly [erythropoietin, sodium selenate]. (Ben.,et al., 2006).Oxidative stress, increased lipid peroxidation and decreased activity of antioxidant system may contribute to the accelerated development of atherosclerosis in chronic renal failure patient during renal replacement therapy, (Mydlik, et al., 2002).

Dietary intake of antioxidants can inhibit or delay oxidation of susceptible cellular substrates and prevent oxidative stress. The phenolic compounds such as flavonoids, phenolic acids, diterpenes, saponins and tannins have received much attention for their high antioxidative activity (Rice-Even et al., 1996 and Abd El-Ghany et al., 2011). Therefore, it is important to enrich our diet with 


\section{Egyptian J. of Nutrition Vol. XXXIII No. 3 (2018)}

antioxidants to protect against many chronic diseases. Moreover, antioxidants play a vital role in food quality preservation due to their ability to prevent oxidative deterioration of lipids (Erukainure et al., 2012). The beneficial effects of natural polyphenolic compounds from vegetables, fruits and nuts are associated with many biological effects, including antioxidant activity and free radicals scavenging properties (Sebai et al., 2013).

Vitamin $E$ protects the cell membrane from lipid per oxidation by forming a low-reactivity tocopheroxyl radical. Vitamin $C$ directly scavenges $\mathrm{O} 2-$ and $\mathrm{OH}$-. Inflammation proteins such as ferritin, transferrin and even albumin exert a non-enzymatic anti-oxidant effect by sequestrating transition metal ions (Canaud, et al., 1999).

In children with End-stage renal disease (ESRD) treated with dialysis reduced total antioxidant status (TAS) coexists with enhanced intracellular oxidative stress in $\mathrm{T}$ lymphocytes (Locatelli\& Del., 2004). The combined treatment with vitamin $E$ and $N$ acetylcysteine NAC lead to the reduction in oxidative stress within Tcells that might be of therapeutic value in dialyzed patients (Zaniew, et al., 2005).

Oxalosis can be a problem in renal failure. As vitamin $\mathrm{C}$ is a precursor of oxalate in patient on regular hemodialysis. Certain results suggested that hyperoxalomia in regular hemodialysis patients is aggravated by routine vitamin $\mathrm{C}$ supplementation. The administration of vitamin $C$ should be restricted to a dose necessary to correct vitamin $\mathrm{C}$ deficiency. (Ono, 1999).

The increased oxidative stress and attendant increased oxidizability of lipoprotein, such as LDL could contribute to the 


\section{Rasha Haji Hassan Ashkanani}

accelerated atheroscierosis in dialysis patients, since alpha-

tocopherol in the major antioxidationLDL. Alpha-tocopherol supplementation may also provide a measure of protein against CVD in patient with chronic kidney failure on dialysis therapy, (Is/am, et al., 2000).

The oxidation damage of RBC membranes in hemodialysis patient increased red blood cell susceptibility to hemodialysis and impairs cell survival. RBC survival close to normal and sufficient correction of anemia is achieved only when appropriate alphatocopherol levels are reached, (Usberti, et al., 2002).

The mechanisms of Vitamin E supplementation caused an increase in glutathione peroxidase and super oxide mutase activities and decrease in thiobarbituric acid reactive substances. (Giray, et al., 2003).

The main objective of the present study is to evaluate the ability of the antioxidants (Vit. C, Vit. E \& Selenium) supplement with diet to prevent the development on chronic renal failure in the experimental rats.

\section{Materialsand Methods}

\section{Material}

Ascorbic acid, vitamin E, selenium (sodium selenite), casein, alanine, all vitamins and minerals were obtained from El-Gomhoreya Company, Cairo, Egypt. Forty two adult male albino rats (SpargueDawely Strain)weighing about 170 10 gmwere obtained from the laboratory animal colony. Ministry of Health and Population, Helwan, Cairo, Egypt. 


\section{Chemicals:}

All chemicals used in this experiment were of analytical grade. Kits used for the quantitative determination of the different parameters were purchased from Biodiagnostic Co., Dokki, Giza, Egypt. Casein (85\% protein), vitamins and minerals constituents were obtained from El-Gomhoriya company for trading Drugs, Chemicals and Medical Instruments Pharm. and Chem. Ind. Co., Cairo, Egypt. Cellulose and D-L, and corn oil and corn starch were obtained from the local market.

\section{Methods:}

\section{Biological Investigation:}

Rats were housed in well aerated cages under hygienic condition and fed on basal diet for one week for adaptation adlibitum. The basal diet consists of $14 \%$ casein (protein $\geq 80 \%$ ), corn oil $4 \%$, cellulose $5 \%$, vitamin mixture $1 \%$ (Campbell., 1959), salt mixture 3.5\% (Hegested., 1941), choline choloride 0.25 and the remainder is corn starch (Reeves et al., 1993).

After an acclimatization period of a week, rats $(n=42)$ were randomly divided into six equal groups and treated for four consecutive weeks. The first group fed on basal diet without supplement until the end of the study (control group). The second group fed on basal diet containing adenine $(0.75 \%$, w/W, in feed) (adenine diet) as a positive control group. The third group fed on adenine diet supplemented with $3 \mathrm{~g}$ vitamin $\mathrm{C} / \mathrm{kg}$. The fourth group was given adenine diet supplemented with $900 \mathrm{mg}$ vitamin $E / \mathrm{kg}$, and the fifth group was given adenine diet supplemented with $0.1 \mathrm{ppm}$ of selenium as selenite. The sixth group was given adenine diet supplemented with antioxidants mixture. After 5 weeks rats will be 


\section{Rasha Haji Hassan Ashkanani}

scarified, some organs removed, weighed, and blood sample will be collect and centrifuges to obtain the serum.

\section{Biological Evaluation:}

Biological Evaluation of the different diets was carried out by determination of feed intake, body weight gain \% and organs weight $/$ body weight \% according to (Chapman et al., 1959). Serum uric acid was determined according to the method described by Fossatiand Principe(1982). Urea nitrogen was determined in the serum according to the method described by (Patton and Crouch, 1977). Creatinine was determined according to the method described by (Bartels and Bohmer, 1971). Aspartate amine transaminases (AST) and Alanine amine transaminases (ALT) were measured according to the method described by (Reitman and Frankel, 1957).

The blood hemoglobin concentration was determined by cyanmethemoglobin method using Drabkin's solution as a dilute. Whole blood was drawn into a heparized micro capillary tube, sealed and centrifuged for four minutes. The percentage volume of packed red cells to that of whole blood was determined on a micro-hematocrit tube reader. Red blood cell and white blood cell count was determined by means of Coulter Count Apparatus. (Drakin, 1949).

\section{Histobathological examination:}

Specimens for kidney tissues were taken immediately after sacrificing animals and fixed in $10 \%$ buffered neutral formalin solution. The fixed speomens were then trimmed, washed and dehydrated imbedded in paraffin, cut in sections of 46 microns thickness and stained with haematoxylin and eosin stain, according to (Sheehan and Hrapchak., 1980). 
Egyptian J. of Nutrition Vol. XXXIII No. 3 (2018)

\section{Statistical analysis}

Data are presented as means $\pm S D$ and the analysis was conducted using SPSS program, Version 16.0 (2007).

\section{Results and Discussion}

Effect of vit. $\mathrm{C}$, vit. $\mathrm{E}$, selenium and their mixture on $\mathrm{FI}, \mathrm{BWG} \%$ and Organs weight / body weight $\%$ in rats suffering from chronic renal failure:

\section{Feed intake ( $g /$ day/each rat):}

The mean value of feed intake ( $\mathrm{g} /$ day/ each rat) of the negative control group increased than that of the positive control group (rat suffering from chronic renal failure) The mean value of feed intake of all treated groups with all types of antioxidants which were used in this study increased than that of the control ( + group. The lowest feed intake recorded for the group which treated with vit. $C$, followed by the group treated with vit. $E$, respectively (Table 1).

\section{Body weight gain \%:}

The mean value of body weight gain $\%$ of positive group decreased significantly pl] 0.05 , as compared to the healthy group and treated groups. Treating rats which suffer from chronic renal failure with antioxidants diet containing selenium and antioxidants mixture led to significant increase in body weight gain $\%$, as compared to the positive control group. The results in table (1) indicated that, non-significant changes in body weight gain $\%$ between the groups which were treated with vitamin $C$ and vitamin $E$. 


\section{Rasha Haji Hassan Ashkanani}

\section{Organs weight /body weight \%:}

Spleen, brain, kidney and liver weights/body weight\% increased significantly $\mathrm{Pl} 0.05$ in the positive control group (rats suffering from chronic renal failure), as compared to the negative control group, while heart weight / body weight showed nonsignificant change. Feeding group which were suffer from chronic renal failure on adenine diet containing vit. $C$, vit. E, selenium and their mixture induced significant decrease Pl 0.05 in liver, spleen, brain and kidney weight/body weight\%, as compared to the positive control group.

Effect of vit. C, vit. E, selenium and their mixture on kidney function of rats suffering from chronic renal failure:

Uric acid value, urea nitrogen and creatinine $(\mathrm{mg} / \mathrm{dl})$ of the control positive group showed significant increase $(P \leq 0.05)$ as compared to (control -) group.Results in Table (2) indicated that, treated chronic renal failure groups with vit. $C, V i t . E$, selenium and their mixture showed decrease in serum uric acid e the group treated with selenium and also group which treated with mixture of all antioxidants, especially when compared with the positive control groups.

Also, our data agreed with (Han-Yao., 2005) who reported, supplementation with vitamin $C$ at $500 \mathrm{mg} /$ day for 2 months reduced serum uric acid concentration. The data presented in the same table revealed that, the highest decrease in serum urea nitrogen in all treated groups was found in the group fed on antioxidants mixture diet.Fryer., (2000) Reported that vitamin $E$ therapy is also considered as means of correcting plasma antioxidant status and attenuating the cardiovascular disease that accompanies kidney failure. Also, our results were agree with (Ratna and Vasudha., 2009) who reported 
Egyptian J. of Nutrition Vol. XXXIII No. 3 (2018)

that, supplementation with antioxidant vitamins serves as a method of preventing oxidative stress among patients with renal disease.

All treated groups with vit. C, Vit. E, selenium and antioxidant mixture showed decrease in urea nitrogen when compared with the positive control groups, especially the group which treated with all antioxidants. Our results in the same line with (Gholam and Samira., 2013) who explain the positive effects of Seleniumsupplementation on serum blood urea nitrogen and creatinine changes in response to intense exercise in donkey. The positive effect of Selenium might be related to the incorporation of selenium into proteins such as selenocysteine and its preventive role on tissue oxidative damages. All treated groups showed significant decrease in the mean value of serum creatinine as compared to the positive control group.

Effect of vit. $C$, vit. $E$, selenium and their mixture on liver enzymes (IU/L) in rats suffering from chronic renal failure:

Results of AST and ALT are presented in Table (3), AST and ALT enzymes in all treated groups recorded significant decrease $(P<0.05)$ when compared with (control +$)$. The best results in AST and $A L T$ enzymes recorded for the group treated with Vit. $E$ and the group which treated with mixture of (Vit. C, Vit. E and selenium). ElBoshy et al., (2015) reported thatselenium has ameliorated the cadmium-induced liver and kidney damage by improving hepatic and renal markers. Selenium has the potential to countermeasure the immunosuppressive as well as hepatic and renal oxidative damage induced by cadmium in rats; selenium has shown promising effects against Cadmium toxicity. Also, Administration of vitamin $\mathrm{C}$ and Selenium exhibited protective effect by inhibiting methomylinduced toxicity in liver and kidney (Djeffal et al., 2015). 


\section{Rasha Haji Hassan Ashkanani}

Effect of vit. C, vit. E, selenium and their mixture on $\mathrm{Hb}$ (gm/dl), RBC $\left(10^{6 /} \mathrm{mm}^{3)}\right.$ and WBC $\left(10^{3 /} \mathrm{mm}^{3}\right)$ levels in rats suffering from chronic renal failure:

Data in Table (4) showed that, $\mathrm{Hb}(\mathrm{gm} / \mathrm{dl})$ and RBC levelsin positive control group decreased, as compared to negative control group (14.263 $\pm 0.380 \& 4.680 \pm 0.030)$ vs. $(14.480 \pm 0.635 \& 5.313 \pm$ $0.065)$ respectively. While WBC increased significantly. The mean values of $\mathrm{Hb}$ and $\mathrm{RBC}$ increased in the groups which treated with antioxidants as compared to the positive control group. On the other hand, feeding rats on antioxidantsshowed significant ( $P \leq 0.05)$ decrease in WBC $\left(10^{3 /} \mathrm{mm}^{3}\right)$ levels as compared to positive control group.

Our results in the same line with Hossen et al., (2017), who showed that turmeric contains high concentrations of polyphenols, flavonoids, ascorbic acid. Oral administration of carbofuran caused significant changes in some of the blood indices, such as corpuscular hemoglobin, white blood cell, platelet distribution width and induced severe hepatic injuries associated with oxidative stress, as observed by the significantly higher lipid peroxidation levels when compared to control, while the activities of cellular antioxidant enzymes were significantly suppressed in the liver tissue. Turmeric supplementation could protect against carbofuran-induced hematological perturbations and hepatic injuries in rats, plausibly by the up-regulation of antioxidant enzymes and inhibition of lipid peroxidation to confer the protective effect.From these results, it could be recommended that consuming adequate amount of antioxidants from foods and added selenium to bread and bakery. In addition, antioxidants mixture must be added to drinks such as with milk or foods. 
Egyptian J. of Nutrition Vol. XXXIII No. 3 (2018)

Histopathological examination of kidneys:

Microscopically, Kidneys of rat from group 1 revealed the normal histological structure of renal parenchyma (Figs. 1 \& 2). Meanwhile, kidneys of rats from group 2 showed congestion of periglomerular blood vessels, thickening of the glomerular basement membrane (Fig. 3) and vacuolation of epithelial lining renal tubules (Fig. 4). Some examined sections from group 3 revealed congestion of glomerular tuft (Fig. 5), whereas, other sections from this group showed no histopathological changes (Fig. 6). Moreover, slight congestion of the glomerular tuft was the only histopathological change observed in kidneys of rats from group 4 (Fig. 7). Kidney of rat from group 5 showing slight congestion of glomerular tuft (Fig. 8). Kidneys of rats from group 6 revealed no histopathological changes (Fig.9\& 10). 


\section{Rasha Haji Hassan Ashkanani}

Table (1): Effect of vit. C, vit. E, selenium and their mixture on Fl, BWG\% and Organs weight $/$ body weight $\%$ in rats suffering from chronic renal failure

\begin{tabular}{|c|c|c|c|c|c|c|c|}
\hline \multirow[b]{2}{*}{ Groups } & \multirow[b]{2}{*}{$\begin{array}{c}\text { Fl } \\
\text { g/Day }\end{array}$} & \multirow[b]{2}{*}{$\begin{array}{c}\text { BWG\% } \\
\text { Mean } \\
\pm S D\end{array}$} & \multicolumn{5}{|c|}{ Organs weight / body weight $\%$} \\
\hline & & & $\begin{array}{l}\text { Spleen } \\
\text { Mean } \\
\pm S D\end{array}$ & $\begin{array}{c}\text { Brain } \\
\text { Mean } \\
\pm S D\end{array}$ & $\begin{array}{c}\text { Kidney } \\
\text { Mean } \\
\pm S D\end{array}$ & $\begin{array}{l}\text { Heart } \\
\text { Mean } \\
\pm S D\end{array}$ & $\begin{array}{c}\text { Liver } \\
\text { Mean } \\
\pm S D\end{array}$ \\
\hline $\begin{array}{c}\text { Control } \\
(-)\end{array}$ & 12.25 & $\begin{array}{l}31.77 \pm \\
0.977^{A}\end{array}$ & $\begin{array}{c}0.23 \pm \\
0.015^{B C}\end{array}$ & $\begin{array}{l}0.76 \pm \\
0.01^{8}\end{array}$ & $\begin{array}{c}0.68 \pm \\
0.015^{\mathrm{B}}\end{array}$ & $\begin{array}{c}0.35 \pm \\
0.010^{8}\end{array}$ & $\begin{array}{l}3.36 \pm \\
0.050^{c}\end{array}$ \\
\hline $\begin{array}{c}\text { Control } \\
(+)\end{array}$ & 7.50 & $\begin{array}{l}-19.66 \pm \\
0.610^{D E}\end{array}$ & $\begin{array}{c}0.39 \pm \\
0.020^{A}\end{array}$ & $\begin{array}{l}1.11 \pm \\
0.10^{A}\end{array}$ & $\begin{array}{c}0.90 \pm \\
0.026^{A}\end{array}$ & $\begin{array}{l}0.38 \pm \\
0.008^{8}\end{array}$ & $\begin{array}{l}4.16 \pm \\
0.140^{A}\end{array}$ \\
\hline $\begin{array}{l}\text { Vit. C } \\
(3 \mathrm{gm})\end{array}$ & 8.30 & $\begin{array}{c}-18.86 \pm \\
0.843^{c}\end{array}$ & $\begin{array}{c}0.24 \pm \\
0.041^{8 c}\end{array}$ & $\begin{array}{c}0.86 \pm \\
0.110^{A B}\end{array}$ & $\begin{array}{c}0.72 \pm \\
0.010^{A B}\end{array}$ & $\begin{array}{c}0.33 \pm \\
0.037^{8}\end{array}$ & $\begin{array}{l}3.81 \pm \\
0.210^{B}\end{array}$ \\
\hline $\begin{array}{c}\text { Vit. E } \\
\text { (900 mg) }\end{array}$ & 10.17 & $\begin{array}{l}-17.57 \pm \\
0.440^{\mathrm{CD}}\end{array}$ & $\begin{array}{c}0.27 \pm \\
0.020^{8}\end{array}$ & $\begin{array}{c}0.73 \pm \\
0.090^{\mathrm{B}}\end{array}$ & $\begin{array}{c}0.77 \pm \\
0.058^{A B}\end{array}$ & $\begin{array}{c}0.33 \pm \\
0.058^{8}\end{array}$ & $\begin{array}{c}3.76 \pm \\
0.150^{8}\end{array}$ \\
\hline $\begin{array}{l}\text { Selenium } \\
(0.1 P P M)\end{array}$ & 10.61 & $\begin{array}{c}-17.36 \pm \\
0.986^{E}\end{array}$ & $\begin{array}{c}0.21 \pm \\
0.020^{c}\end{array}$ & $\begin{array}{c}0.63 \pm \\
0.249^{8}\end{array}$ & $\begin{array}{c}0.73 \pm \\
0.098^{\text {Aa }}\end{array}$ & $\begin{array}{c}0.31 \pm \\
0.111^{8}\end{array}$ & $\begin{array}{l}3.48 \pm \\
0.180^{c}\end{array}$ \\
\hline $\begin{array}{l}\text { Antioxidant } \\
\text { s mixture }\end{array}$ & 11.07 & $\begin{array}{c}-10.80 \pm \\
0.571^{8}\end{array}$ & $\begin{array}{c}0.27 \pm \\
0.020^{8}\end{array}$ & $\begin{array}{c}0.65 \pm \\
0.319^{8}\end{array}$ & $\begin{array}{c}0.70 \pm \\
0.223^{8}\end{array}$ & $\begin{array}{l}0.317 \pm \\
0.110^{\mathrm{a}}\end{array}$ & $\begin{array}{c}3.74 \pm \\
0.200^{8}\end{array}$ \\
\hline
\end{tabular}

Control (-): Control negative

Control (+): Control positive

FI: Feed Intake

BWG\%: Body weight gain

Vit. C: Vitamin C (Ascorbic Acid)

Vit. E: Vitamin E

SD: Standard Deviation

Mean with the same letter in each column are not significant different $(\mathrm{P}<0.05)$. 
Egyptian J. of Nutrition Vol. XXXIII No. 3 (2018)

Table (2): Effect of vit. $C$, vit. E, selenium and their mixture on serum uric acid, urea nitrogen and creatinine levels $(\mathrm{mg} / \mathrm{dl})$ in rats suffering from chronic renal failure

\begin{tabular}{|c|c|c|c|}
\hline Groups & $\begin{array}{c}\text { Uric acid } \\
\text { Mean } \pm \text { SD }\end{array}$ & $\begin{array}{c}\text { Urea nitrogen } \\
\text { Mean } \pm S D\end{array}$ & $\begin{array}{l}\text { Creatinine } \\
\text { Mean } \pm \text { SD }\end{array}$ \\
\hline Control (-) & $1.523 \pm 0.0416^{8}$ & $17.430 \pm 0.390^{8}$ & $0.470 \pm 0.140^{F}$ \\
\hline Control (+) & $2.943 \pm 0.156^{A}$ & $27.243 \pm 0.698^{A}$ & $3.198 \pm 0.030^{4}$ \\
\hline Vit. C (3 gm) & $2.440 \pm 0.440^{A}$ & $24.366 \pm 0.313^{A}$ & $3.020 \pm 0.040^{C}$ \\
\hline Vit. E $(900 \mathrm{mg})$ & $2.436 \pm 0.353^{A}$ & $24.566 \pm 1.020^{A}$ & $1.840 \pm 0.051^{E}$ \\
\hline Selenium (0.1 PPM) & $1.720 \pm 0.320^{8}$ & $24.796 \pm 2.290^{A}$ & $2.230 \pm 0.048^{\circ}$ \\
\hline Antioxidants mixture & $1.603 \pm 0.430^{8}$ & $20.266 \pm 0.746^{8}$ & $1.630 \pm 0.067^{8}$ \\
\hline
\end{tabular}

Control (-): Control negative Control (+): Control positive

Vit. C: Vitamin C (Ascorbic Acid)

Vit. E: Vitamin $E$

SD: Standard Deviation

Mean with the same letter in each column are not significant different $(P<0.05)$. 


\section{Rasha Haji Hassan Ashkanani}

Table (3): Effect of vit. $C$, vit. E, selenium and their mixture on liver functions (IU/L) in rats suffering from chronic renal failure

\begin{tabular}{|c|c|c|}
\hline $\begin{array}{l}\text { Parameters } \\
\text { Groups }\end{array}$ & $\begin{array}{c}\text { AST } \\
\text { Mean } \pm \text { SD }\end{array}$ & $\begin{array}{c}\text { ALT } \\
\text { Mean } \pm S D\end{array}$ \\
\hline Control $(-)$ & $25.560 \pm 1.396^{\circ}$ & $77.450 \pm 7.830^{8}$ \\
\hline Control $(+)$ & $35.966+2.140^{4}$ & $117.680+7.810^{4}$ \\
\hline Vit. $C(3 \mathrm{gm})$ & $26.403 \pm 1.721^{6}$ & $112.780 \pm 8.540^{7}$ \\
\hline Vit. E (900 mg) & $28.123 \pm 1.372^{C}$ & $94.520 \pm 3.910^{8}$ \\
\hline Selenium (0.1 PPM) & $31.413 \pm 1.374^{8}$ & $87.340 \pm 3.850^{8}$ \\
\hline Antioxidants mixture & $27.296 \pm 0.117^{6}$ & $86.840 \pm 2.630^{8}$ \\
\hline
\end{tabular}

Control (-): Control negative

Control (+): Control positive

Vit. C: Vitamin C (Ascorbic Acid)

Vit. E: Vitamin E

AST: Asparate Aminotransferase

ALT: Alanine Aminotransferase

$\mathrm{SD}$ : Standard Deviation

Mean with the same letter in each column are not significant different $(P<0.05)$ 
Egyptian J. of Nutrition Vol. XXXIII No. 3 (2018)

Table (4): Effect of vit. C, vit. E, selenium and their mixture on $\mathrm{Hb}$ $(\mathrm{gm} / \mathrm{dl}), \mathrm{RBC}\left(10^{6 /} \mathrm{mm}^{3)}\right.$ and WBC $\left(10^{3 /} \mathrm{mm}^{3}\right)$ levels in rats suffering from chronic renal failure

\begin{tabular}{l|c|c|c}
\hline \multicolumn{1}{c|}{ Parameters } & $\begin{array}{c}\mathrm{Hb} \\
\text { Groups }\end{array}$ & $\begin{array}{c}\text { RBC } \\
\text { Mean } \pm \text { SD }\end{array}$ & $\begin{array}{c}\text { WBC } \\
\text { Mean } \pm \text { SD }\end{array}$ \\
\hline Control (-) & $14.480 \pm 0.635^{\mathrm{C}}$ & $5.313 \pm 0.065^{\mathrm{A}}$ & $30.673 \pm 0.485^{\mathrm{CD}}$ \\
\hline Control (+) & $14.263 \pm 0.380^{\mathrm{C}}$ & $4.680 \pm 0.030^{\mathrm{A}}$ & $40.590 \pm 0.752^{\mathrm{A}}$ \\
\hline Vit. C (3 gm) & $16.746 \pm 0.299^{\mathrm{A}}$ & $5.120 \pm 0.471^{\mathrm{A}}$ & $31.450 \pm 0.248^{\mathrm{B}}$ \\
\hline Vit. E (900 mg) & $15.130 \pm 1.150^{\mathrm{BC}}$ & $5.573 \pm 0.452^{\mathrm{A}}$ & $32.813 \pm 1.437^{8}$ \\
\hline Selenium (0.1 PPM) & $14.746 \pm 0.313^{\mathrm{C}}$ & $5.076 \pm 1.061^{\mathrm{A}}$ & $29.130 \pm 0.640^{\mathrm{O}}$ \\
\hline Antioxidants mixture & $16.130 \pm 1.005^{\mathrm{AB}}$ & $5.146 \pm 0.142^{\mathrm{A}}$ & $29.790 \pm 0.380^{\mathrm{D}}$ \\
\hline Control
\end{tabular}

Control (-): Control negative

Control (+): Control positive

Vit. C: Vitamin C (Ascorbic Acid)

Vit. E: Vitamin $E$

$\mathrm{Hb}$ : Blood Hemoglobin Concentration

SD: Standard Deviation

RBC: Red Blood Cells

WBC: White Blood Cells

Mean with the same letter in each column are not significant different $(P<0.05)$. 


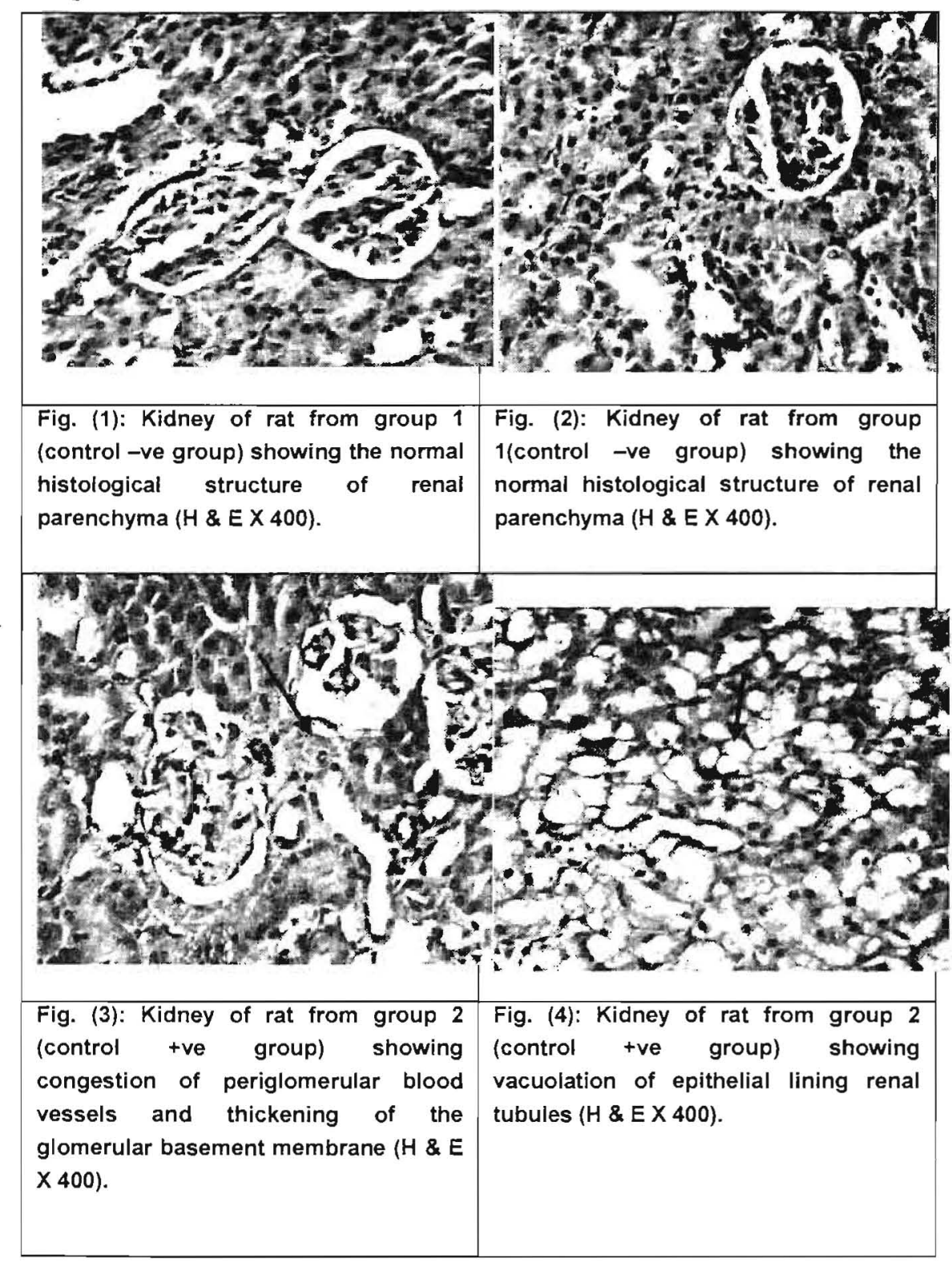




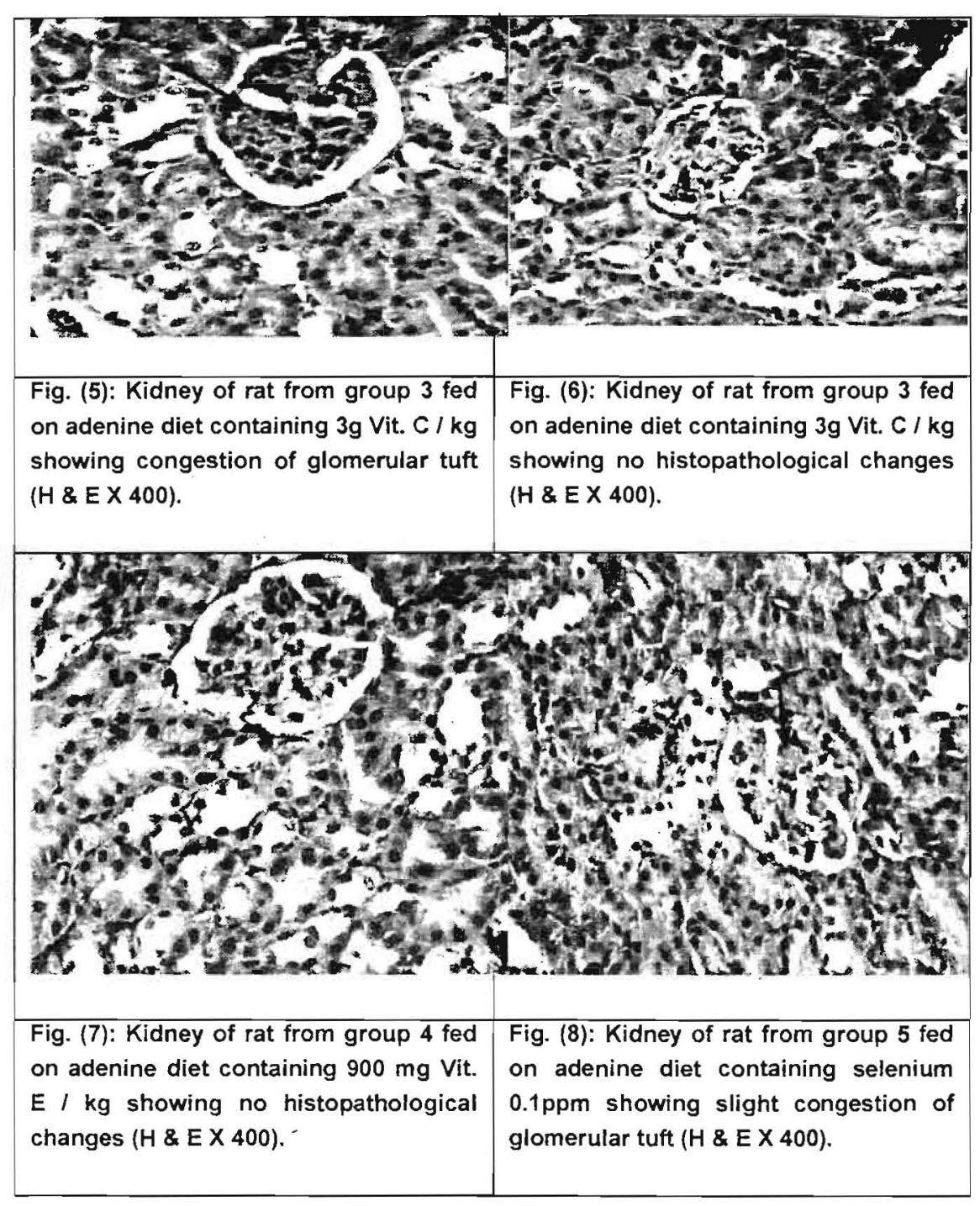




\section{Rasha Haji Hassan Ashkanani}

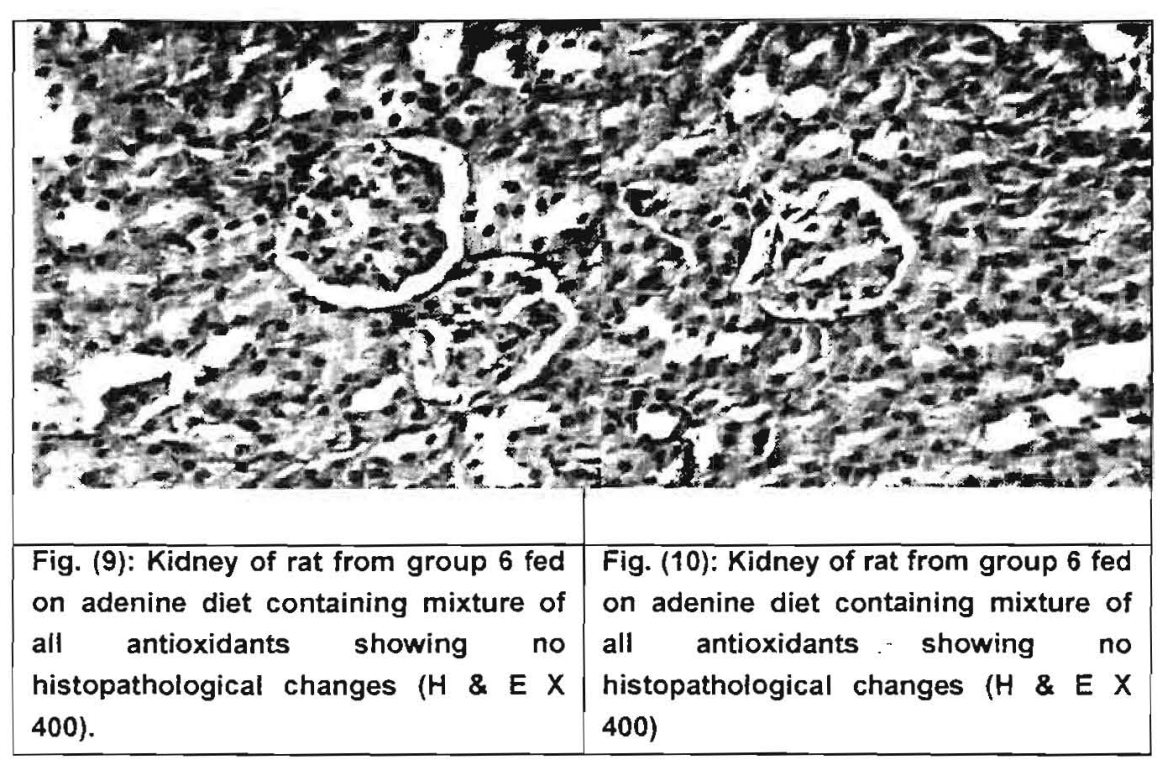


Egyptian J. of Nutrition Vol. XXXIII No. 3 (2018)

\section{References}

Abd El-Ghany, M.; Ramadan, A. and hassanan, S. (2011):

Antioxidant activity of some agro-industrial peeis on liver and kidney of rats exposed to oxidative stress. World J. Dairy Food sci.; $6(1)$ : 105-114

Bartels, H. and Bohmer, M.(1971):

Creatinine standard and measurement of serum creatinine with picric acid.Clin. Chem.,acta, International Journal of Clinical Chemistry and Diagnostic Laboratory Medicine $.32: 81$

Ben, I; Green, Y; Nakhoul, F; Kanter, Y. and Nagler, R.M. (2006): Effects of Diabetes Mellitus, Chronic Renal Failure and Hemodialysis on Serum and Salivary Antioxidant Status. Nephron Clin Pract.29; 105 (3): c114-c120.

Canaud, B; Cristol, J.P; Morena, M; Leray-Moragues, H; Bosc, J.Y. and Vaussenat, F. (1999):

Imbalance of oxidants and antioxidants in hemodialysis patients. Blood Purif. Kidney Int. Journal., 17:99-106.

Chapman, D.G.; Castilla, R. and Campbell, J.A. (1959): Evaluation of protein in food. I.A. Method for the determination of protein efficiency ratio. Can. J. Biochem. Physiol, 37:679-686.

Djeffal, A.; Messarah, M.; Boumendjel, A.; Kadeche, L. andFeki, AE. (2015):

Protective effects of vitamin $\mathrm{C}$ and selenium supplementation on methomyl-induced tissue oxidative stress in adult rats. Toxicollnd Health. 31(1):31-43.

Drakin, D.L. (1949):

The standardization of hemoglobin measurement. Amer. J. Med. Sci., V. 217:710. 
El-Boshy, M.E.; Risha, E.F.; Abdelhamid, F.M.; Mubarak, M.S.and Hadda T.B. (2015):

Protective effects of selenium against cadmium induced hematological disturbances, immunosuppressive, oxidative stress and hepatorenal damage in rats.J Trace Elem Med Biol. 29:104-10.

Erukainure, O. L.; Oke, O.V.; owolable, F.O.; kayoed, F.O.; Umanhonlen, E.E. and Aliyu, M. (2012):

Chemical properties of Monodoramyristica and its protective potential against free radical in vitro. Oxid. Antioxid. Med. Sci.; $1(2): 127-132$

Fossati, P.; and Principe, L. (1982):

Enzymatic colorimetric method to determination triglycerides. J.Clin. Chem., 28:2077

Fryer, J. M. (2000):

Vitamin $E$ as a protective antioxidant in progressive renal failure. Nephrology. $5(1-2): 1-7$

Giray, B; Kan, E; Bali, M; Hincal, F. and Basaran, N. (2003):

The effect of vitamin $E$ supplementation on antioxidant enzyme activities and lipid per oxidation levels in hemodialysis patients. ClinChimActa. 338(1-2):91-8.

Gholam, A.; Samira, S. (2013):

Preventing Effects of Nano-Selenium Particles on Serum Concentration of Blood Urea Nitrogen, Creatinine, and Total Protein During Intense Exercise in Donkey, Journal of Equine Veterinary Science.Volume 33, Issue 8, Pages 597-600.

Han-Yao Huang; Lawrence J. Appel; Michael J. Choi; Allan C. Gelber, Jeanne Charleston; Edward P. Norkus, and Edgar R. Miller (2005):

The Effects of Vitamin C Supplementation on Serum Concentrations of Uric Acid Results of a Randomized Controlled Trial.

ARTHRITIS \& RHEUMATISM. Vol. 52, No. 6, pp 1843-1847. 
Hegseted, D. M.; Mills, R. C.; Elvehjem, C. A. and Hart, E. B. (1941):

Choline in the nutrition of chicks. J. Biol. Chem.; 138: 459470 .

Hossen, M.S.; Tanvir, E.M.; Prince,M.B.; Paul, S.; Saha, M.; Ali, M.Y.; Gan,S.H.; Khalil,M.I. \&Karim N.(2017):

Protective mechanism of turmeric (Curcuma longa) on carbofuran-induced hematological and hepatic toxicities in a rat model. Pharm Biol. 55(1):1937-1945.

Islam, K.N;'Byrne, D; Devaraj, S; Palmer, B; Grundy, S.M. and Jialal, I. (2000):

Alpha-tocopherol supplementation decreases the oxidative susceptibility of LDL in renal failure.patients on dialysis therapy. J. Atherosclerosis. 150(1):217-24.

Locatelli, F. and Del Vecchio, L. (2004):

Nutrition for children with chronic kidney. The National Institute of Diabetes and Digestive and Kidney Diseases (NIDDK) .Volume 11, Issue 2, Pages 162-171 (April).

Mydlik, M; Derzsiova, K; Racz, O; Sipulova, A; Boldizsar, J; Lovasova, E and Hribikova, M. (2002):

Vitamin $E$ as an antioxidant agent in $C A D$ patients. Oxford Journals. MedicineQJM: An International Journal of Medicine. Volume 92, Issue 5. Pp. 239-244.

Ono, K. (1999):

Secondary hyperoxalemia caused by vitamin $C$ supplementation in regular hemodialysis patients. CHEST Journal. CHEST August 2000 vol. 118 no. 2 561-563

Patton, C.J. and Crouch, S.R. (1977):

Enzymatic colorimetric method to determination urea in serum. Anal. Chem., 49:464. 


\section{Rasha Haji Hassan Ashkanani}

Ratna P. and Vasudha K. C. (2009):

Antioxidant vitamins in chronic renal failure. Biomedical Research. Volume 20, Issue 1

Reeves, P. G.; Nielsen, F. H. and Fahmy, G. C. (1993): Reported of the American Institute of Nutrition adhocwriling cornmittee on the reformulation of the AIN-76 A Rodent diet. J. Nutr.; 123: $1939-1951$

Reitman, S. and Frankel, S. (1957):

A colorimetric method for the determination of serum glutamic oxaloacetic and glutamic pyruvic transaminase. Am. J.clin.Path. 28-56.

Rice-Evans, C. A.; Miller, N.J. and Paganga, G. (1996):

Structure-antioxidant activity relationships of flavonoids and phenolic acids. Free Radic. Biol. Med.; 20 (7): 933-956.

Sebai, H.; Selmi, S.; Rtibi, K.; Souli, A.; Gharbi, N.; and Sakly, M. (2013):

Lavender essential oils attenuate hyperglycemia and protect against oxidative stress in alloxan-induced diabetic rats. Lipids health Dis; ; $12(1):$ 189-195.

Sheehan, D. and Harpchak, B. (1980):

Phory and Bractec Histology. $2^{\text {nd }}$ ed. Battle-Press; Ohio.

SPSS. (2007):

Statistical Package for Social Science, SPSS Inc, version 16.0 Chicago, IL.

Usberti, M; Gerardi, G; Bufano, G; Tira, P; Micheli, A; Albertini, A; Floridi, A; Di Lorenzo, D. and Galli, F. (2002):

Effects of erythropoi-etin and vitamin E-modified membrane on plasma oxidative stress markers and anemia of hemodialyzed patients. Am J Kidney Dis. 2002 Sep;40(3):590-9. 
Egyptian J. of Nutrition Vol. XXXIII No. 3 (2018)

WesenAdil Mehdi,(2011):

Determination of resistin and several antioxidant in sera of patients with chronic renal failure. Australian of basic and applied sciences, 5 (8): 196-203, 2011. ISSN 1991-8178

Zaniew, M; Zachwieja, J; Warzywoda, A; Stefaniak, E; Runowski, D. and Lewandowska-Stachowiak, M. (2005):

Influence of vitamin $\mathrm{E}$ and $\mathrm{N}$-acetylcysteine on intracellular oxidative stress in T-lymphocytes in children treated with dialysis. WiadLek., 58 Suppl 1:58-65. 


\section{Rasha Haji Hassan Ashkanani}

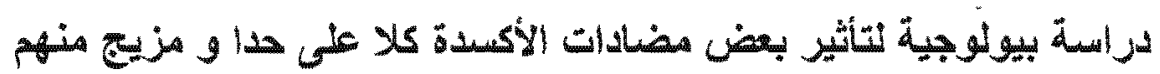

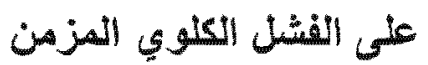 \\ رئا حاجى غُلوم هسن أشنكنانى}

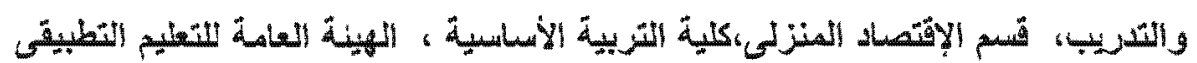
ألكويت

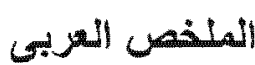

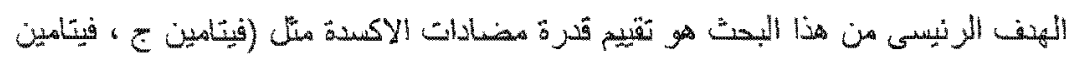

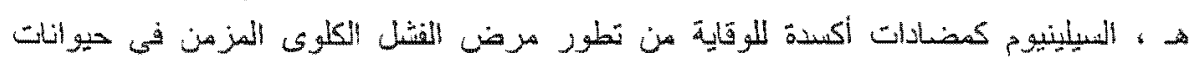

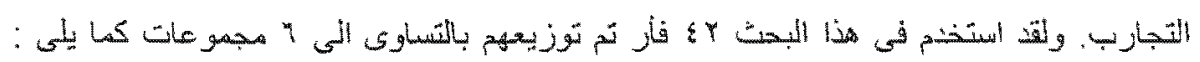

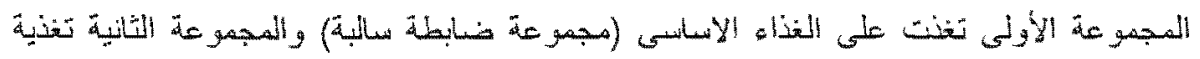

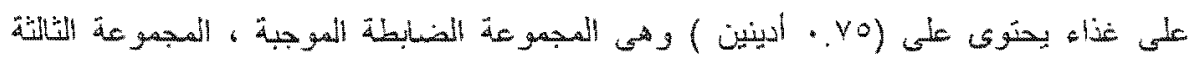

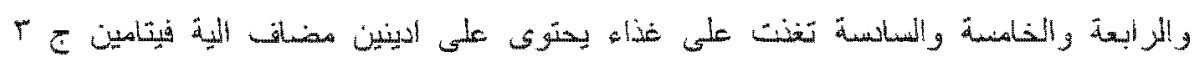

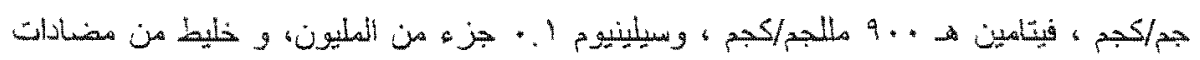

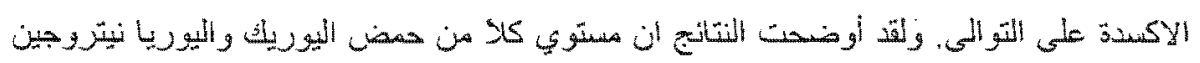

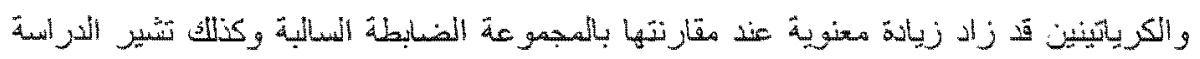

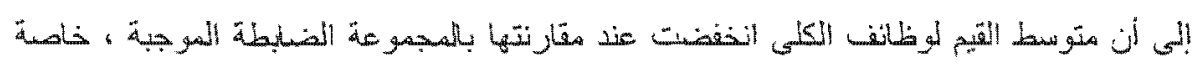

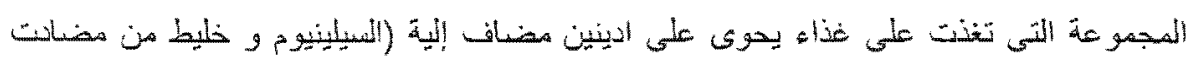

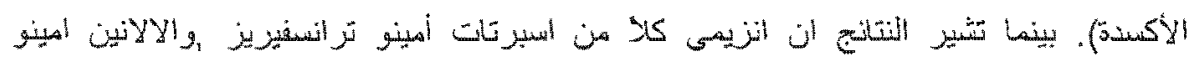

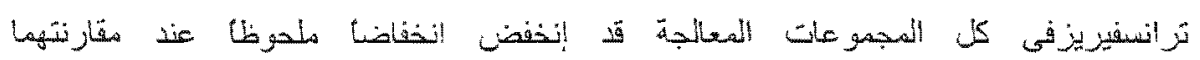

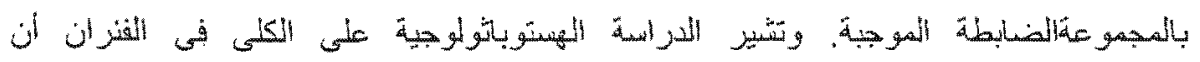

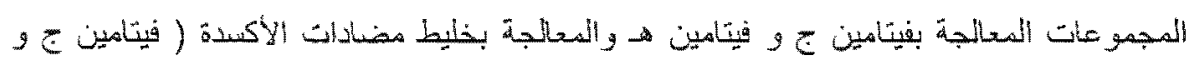

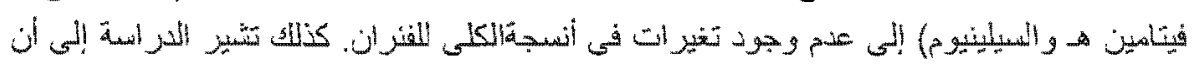

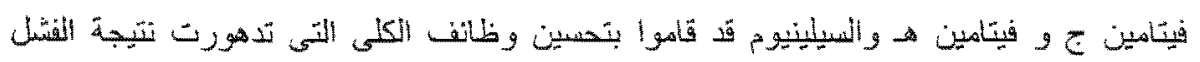

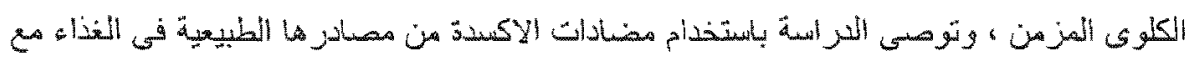

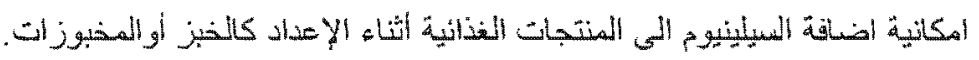

